\title{
Pancasila Values in Social-Cultural Perspective
}

\author{
Yuliana \\ Universitas Udayana, Denpasar, Indonesia \\ yuliana@unud.ac.id
}

\section{Article History}

accepted 23/03/2021

approved 10/04/2021

published 20/04/2021

\begin{abstract}
Pancasila as the country foundation has been unified in our nation lives since the independence day. The five principles are related to each other. Every life aspect is based on Pancasila, especially sociocultural live. In this modern life, Pancasila values have to be remembered. Sociocultural perspective is associated with human resources. Human is sociocultural creature. Good culture is shown from attitude, ethics, and characters. Building good sociocultural need Pancasila values. This positive culture can be developed from ourselves and spread to the society.
\end{abstract}

Keywords: value, Pancasila, perspective, social, culture

\section{Abstrak}

Pancasila sebagai dasar negara sudah menyatu dalam kehidupan bangsa ini sejak jaman kemerdekaan. Lima sila tersebut berkaitan erat satu dengan yang lainnya. Segala sendi kehidupan didasarkan pada Pancasila, terutama kehidupan sosial budaya. Di era kehidupan modern ini, nilai-nilai Pancasila harus tetap diingat. Perspektif sosial dan budaya berhubungan dengan sumber daya manusia. Manusia adalah makhluk sosial, sekaligus makhluk berbudaya. Budaya yang baik tercermin dari sikap, etika, dan karakter. Untuk membangun kehidupan sosial budaya yang baik tidak bisa lepas dari pengamalan nilai-nilai Pancasila. Budaya positif ini bisa dikembangkan mulai dari diri sendiri dan disebarkan ke lingkungan sekitar maupun masyarakat. Kata kunci: nilai, Pancasila, perspektif, sosial, budaya

Social, Humanities, and Education Studies (SHEs): Conference Series https://jurnal.uns.ac.id/shes

p-ISSN 2620-9284

e-ISSN 2620-9292 


\section{PENDAHULUAN}

Pancasila sebagai dasar negara sudah mendarah daging dalam kehidupan rakyat Indonesia. Pancasila ini mulai diajarkan sejak sekolah Taman Kanak-Kanak sampai dengan Perguruan Tinggi. Ada mata pelajaran khusus, seperti Pendidikan Kewarganegaraan. Bahkan setiap upacara bendera, pasti dilafalkan Pancasila. Mengingat sedemikian pentingnya Pancasila dan butir-butir Pancasila dalam pengamalannya, maka hendaknya nilai Pancasila selalu diabadikan dalam kehidupan sehari-hari.

Indonesia sebagai negara kepulauan memiliki jumlah penduduk yang sangat banyak. Tentunya hal ini berdampak pada majemuknya kondisi sosial budaya di Indonesia. Beragam kondisi sosial budaya dan adat istiadat ini, jika tidak dipahami dengan baik akan mudah memicu terjadinya konflik dan perpecahan (Amalia 2013).

Pancasila sebagai lima landasan bangsa Indonesia akan mempersatukan bangsa Indonesia jika dilaksanakan dengan baik. Lambang negara Garuda disimbolkan berupa burung garuda yang memegang sebuah tulisan, yaitu Bhineka Tunggal Ika. Semboyan ini artinya berbeda-beda tetapi tetap satu juga. Hal ini mengandung makna persatuan dalam perbedaan. Semboyan ini jika dipegang kuat akan dapat mengatasi perbedaan sosial budaya di negara Indonesia tercinta (Syamsir et al. 2017).

Indonesia terdiri dari berbagai pulau, ras, kelompok etnis, agama, budaya, dan bahasa tradisional (daerah). Ada banyak bahasa daerah di Indonesia dengan berbagai dialek khasnya. Namun demikian, bahasa nasional Indonesia digunakan di seluruh pelosok negeri ini dan di sekolah-sekolah untuk menciptakan rasa kesatuan dan persatuan (Prayitno 2014).

Seluruh aspek kehidupan bernegara dan bermasyarakat hendaknya didasarkan pada Pancasila. Aspek kehidupan tersebut meliputi kehidupan sosial budaya, politik, beragama di lingkungan masyarakat maupun bernegara. Sosial dan budaya adalah hal penting dalam kehidupan bersama. Menyimpangnya nilai-nilai Pancasila menyebabkan permasalahan dalam persatuan dan kesatuan bangsa Indonesia (Inahasari and Dewantara 2019).

Pengembangan nilai Pancasila di dalam kehidupan sosial budaya terkait dengan kualitas sumber daya manusia. Jika kualitas sumber daya manusia memadai, maka akan tercipta kedamaian dalam tatanan hidup bersama. Rasa aman dan kesejahteraan bersama akan tercipta. Karakter sosial budaya yang kuat akan meningkatkan rasa nasionalisme (Inahasari and Dewantara 2019).

Pancasila mengatur sendi kehidupan berbangsa dan bernegara. Dalam kehidupan sehari-hari, Pancasila berperan untuk mengatur bagaimana membentuk moralitas yang baik dari setiap anggota masyarakat. Setiap individu memiliki ciri khas tersendiri dengan pikiran dan budayanya sendiri. Dengan berpegang pada Pancasila, maka kita akan menghargai berbagai perbedaan yang ada. Pancasila memiliki nilai filsafat luhur (Hoon 2020).

Sosial budaya adalah cerminan kualitas suatu negara. Kehidupan sehari-hari tidak bisa lepas dari sosial budaya. Sosial artinya berinteraksi dengan orang lain dan masyarakat sekitar. Budaya artinya segala sesuatu yang mengandung cita dan rasa (Inahasari and Dewantara 2019).

Kehidupan sosial budaya harus didasarkan pada nilai-nilai Pancasila. Terutama dalam kehidupan modern ini, pengaruh media massa dan komunikasi, internet, maupun majalah cetak dan elektronik sangat besar pada generasi muda. Jika tidak dibentengi dengan baik, maka generasi muda akan mudah terjerumus ke nilai-nilai yang buruk. Dalam kehidupan yang cenderung lebih individualistis sekarang, pengaruh budaya asing cenderung lebih mudah masuk. Budaya yang positif ini bisa dimulai dari diri sendiri dan dikembangkan sebanyak mungkin. Upaya meningkatkan nilai-nilai 
Pancasila dalam kehidupan sosial budaya ini perlu dipahami dan diamalkan dengan baik dan seksama.

\section{METODE}

Tulisan ini merupakan tinjauan pustaka. Mesin pencari yang dipergunakan adalah Google Scholar. Kata kunci yang digunakan adalah Pancasila, sosial, budaya.

\section{HASIL DAN PEMBAHASAN}

Peran Pancasila dalam pengembangan sosial budaya berdasarkan karakter sangatlah besar. Hal ini dapat diwujudkan jika kita mengamalkan Pancasila dengan baik terutama sila kedua dan kelima. Untuk mengamalkan nilai Pancasila dalam kehidupan sosial budaya, maka perlu memahami makna Pancasila.

\section{Makna Pancasila dan Sosial Budaya}

Makna Pancasila adalah sebagai dasar negara dan sendi kehidupan bangsa. Bapak Ir. Soekarno mengatakan bahwa Pancasila adalah filsafat dan jiwa bangsa Indonesia. Pancasila ini sudah ada jauh sebelum Indonesia merdeka. Ada lima prinsip utama dalam Pancasila, yaitu ketuhanan, kebangsaan (bangsa Indonesia), internasionalisme (kemanusiaan), mufakat/permusyawaratan, dan kesejahteraan (keadilan sosial) (Inahasari and Dewantara 2019).

Pancasila adalah ciri khas kekuatan Negara Indonesia. Kehidupan sosial budaya yang berdasarkan nilai Pancasila terkait dengan sila-sila dalam Pancasila, terutama sila kedua, ketiga, dan kelima. Berdasarkan sila kedua Pancasila maka manusia berbudaya hendaknya memiliki rasa kemanusiaan yang adil dan beradab. Menurut sila kelima Pancasila maka manusia yang berjiwa sosial selayaknya mampu mewujudkan kesejahteraan umat manusia di sekelilingnya sesuai kemampuan yang dimilikinya. Sila ketiga berkaitan dengan mengutamakan budaya negara sendiri dibandingkan dengan budaya luar negeri. Sebagai contoh, menggunakan produk dalam negeri, lebih mencintai Bahasa Indonesia, dan mengutamakan budaya yang berasal dari dalam negeri. Bahasa asing boleh dipelajari sebanyak-banyaknya untuk mendukung pendidikan dan pekerjaan, namun Bahasa Indonesia sebagai bahasa nasional tidak boleh ditinggalkan begitu saja (Hoon 2020).

Pancasila ditempatkan sebagai arah perubahan sosial, karena nilai-nilai Pancasila diharapkan dapat mengakomodasi seluruh kepentingan kelompok sosial yang multikultural, multietnis, dan agama. Pancasila memberikan ruang terhadap berkembangnya ideologi sosial politik yang pluralistik. Di dalam Pancasila ditemukan harmonisasi antara perbedaan agama, multikultural, kemajemukan etnis budaya, serta sosial politik. Hal ini dilakukan untuk menghindari segala bentuk konflik (Syamsir et al. 2017).

Perubahan sosial diarahkan pada pengembangan jati diri yang positif untuk mendukung pembangunan nasional. Nilai-nilai Pancasila yang dapat memberikan arah perubahan sosial, yaitu (Prayitno 2014):

1. Karakter "Ketuhanan Yang Maha Esa"

Karakter sila pertama dari Pancasila ini terwujud dalam sikap hormat dan bekerja sama antarpemeluk agama dan penganut kepercayaan. Agama yang diakui di Indonesia ada enam yaitu Islam, Katolik, Hindu, Kristen, Buddha, dan Konghucu. Semua pemeluk agama tersebut saling menghormati dan bebas menjalankan ibadah masing-masing sesuai dengan agama dan kepercayaannya itu. Antar pemeluk agama tidak memaksakan agama dan kepercayaannya kepada orang lain. Sila ini juga mengandung makna supaya masing-masing pemeluk agama saling menghormati untuk terciptanya kehidupan yang serasi, selaras, dan seimbang.

Nilai yang terkandung dalam sila pertama yaitu: 
a. Keyakinan terhadap Tuhan yang Maha Esa

b. Ketakwaan terhadap Tuhan yang Maha Esa dengan menjalankan semua perintah-Nya dan menjauhi larangan-Nya.

c. Saling menghormati dan bertoleransi antara pemeluk agama

d. Bebas menjalankan ibadah sesuai pilihan agama dan kepercayaannya masing-masing di manapun.

e. Selalu bersyukur kepada Tuhan atas kondisi apapun

f. Membina kerukunan hidup di antara sesame umat beragama dan kepercayaan terhadap Tuhan yang Maha Esa

g. Tidak memaksakan suatu agama dan kepercayaan terhadap Tuhan yang Maha Esa kepada orang lain.

2. Perubahan sosial berlandaskan nilai "Kemanusiaan Yang Adil dan Beradab"

Perubahan sosial berdasarkan sila kedua Pancasila ini tercipta dalam wujud perilaku hormat-menghormati antarwarga negara. Ini adalah karakteristik pribadi bangsa Indonesia yang luhur. Karakter kemanusiaan seseorang terlihat dari pengakuan atas persamaan derajat, hak, dan kewajiban, saling mencintai, tenggang rasa, dan tidak semena-mena terhadap orang lain. Gemar melakukan kegiatan kemanusiaan, menjunjung tinggi nilai kemanusiaan, berani membela kebenaran dan keadilan, merasakan dirinya sebagai bagian dari seluruh umat manusia serta mengembangkan sikap hormat-menghormati adalah pengamalan dari butir-butir Pancasila sila kedua.

Nilai-nilai yang terkandung dalam Pancasila sila kedua yaitu:

a. Mengakui persamaan harkat dan martabat manusia

b. Mengakui bahwa semua manusia adalah makhluk ciptaan Tuhan yang paling mulia tanpa membedakan latar belakang agama, suku, ras, status ekonomi, tingkat pendidikan, maupun perbedaan antar golongan.

c. Mengembangkan sikap tenggang rasa

d. Menjunjung tinggi kemanusiaan dan memperlakukan sesama manusia secara adil dan beradab

e. Menolong orang lain yang sedang kesusahan

f. Setiap manusia memiliki hak dan kewajiban yang sama tanpa ada perbedaan apapun

g. Saling menghormati orang lain

3. Perubahan sosial berlandaskan nilai "Persatuan Indonesia"

Perubahan sosial berdasarkan sila ketiga Pancasila ini terwujud dalam kehidupan berbangsa yang mengedepankan persatuan dan kesatuan bangsa di atas kepentingan pribadi, kelompok, dan golongan manapun. Nilai persatuan ini mendamaikan kelompok masyarakat yang memiliki berbagai budaya lokal (setempat), budaya global, budaya bangsa, serta budaya agama dan sistem kepercayaan. Indonesia ini adalah wadah dari terwujudnya kebulatan utuh dalam berbagai aspek kehidupan yaitu ideologi, politik, sosial, budaya, dan pertahanan keamanan.

Nilai-nilai yang terkandung dalam sila ketiga Pancasila adalah:

a. Menempatkan persatuan, kesatuan, kepentingan, serta keselamatan bangsa dan negara di atas kepentingan pribadi dan golongan

b. Cinta tanah air dan rela berkorban demi kepentingan bangsa dan negara

c. Mengakui, menerima, serta menghormati keragaman suku dan budaya bangsa

d. Memakai produk dalam negeri

e. Tidak bersikap sombong

f. Memelihara ketertiban masyarakat dan dunia

g. Memajukan pergaulan demi persatuan dan kesatuan bangsa

h. Menjaga nama baik keluarga, bangsa, dan negara 
4. Perubahan sosial berlandaskan nilai "Kerakyatan yang Dipimpin oleh Hikmat Kebijaksanaan dalam Permusyawaratan/ Perwakilan"

Sila keempat Pancasila mengandung pengertian untuk selalu berusaha mewujudkan kehidupan bangsa yang demokratis, saling bergotong-royong, serta menjunjung tinggi hukum dan hak asasi manusia sebagai wujud nyata dari karakter warga Indonesia yang pokok dalam mendukung pembangunan nasional. Setiap warga negara memiliki kewajiban dan kedudukan yang sama dalam hukum dan pemerintahan.

Nilai-nilai yang terkandung dalam sila keempat Pancasila adalah:

a. Kedaulatan tertinggi ada di tangan rakyat

b. Semua warga negara memiliki kedudukan, hak, dan kewajiban yang sama

c. Berani mengemukakan pendapat saat musyawarah

d. Melaksanakan keputusan musyawarah dengan penuh ikhlas dan tanggungjawab

e. Musyawarah untuk mufakat dilandaskan oleh semangat kekeluargaan

f. Mengutamakan kepentingan negara dan masyarakat di atas kepentingan pribadi dan golongan

g. Mengutamakan musyawarah untuk mufakat dalam mengambil keputusan demi menyelesaikan masalah secara baik dan kekeluargaan

h. Tidak memaksakan kehendak kepada orang lain

i. Menghormati hasil musyawarah

5. Perubahan sosial yang sesuai dengan nilai "Keadilan Sosial Bagi Seluruh Rakyat Indonesia"

Pengamalan sila kelima Pancasila ini terwujud dalam kehidupan berbangsa yang mengedepankan keadilan dan kesejahteraan rakyat. Karakter berkeadilan sosial tercermin dalam perbuatan yang mencerminkan sikap dan suasana kekeluargaan dan kegotongroyongan; sikap adil; menjaga keharmonisan antara hak dan kewajiban; hormat terhadap hak-hak orang lain; suka menolong orang lain; menjauhi sikap pemerasan terhadap orang lain; tidak boros; tidak bergaya hidup mewah; suka bekerja keras; menghargai karya orang lain.

Nilai-nilai yang terkandung dalam sila kelima Pancasila yaitu:

a. Setiap warga negara harus diperlukan secara adil sesuai dengan hak dan kewajibannya tanpa membedakan agama, suku, bahasa, dan status sosial ekonominya

b. Mewujudkan keadilan dalam kehidupan bermasyarakat

c. Menjaga keseimbangan antara hak dan kewajiban

d. Menghormati hak-hak dan kewajiban orang lain

e. Bersikap adil dan suka memberikan pertolongan kepada orang lain

f. Menghargai hasil karya orang lain yang bermanfaat bagi kemajuan dan kesejahteraan bersama

g. Tidak melakukan perbuatan yang merugikan orang lain maupun kepentingan umum

h. Suka bekerja keras

i. Gemar melakukan kegiatan sosial untuk mewujudkan kemajuan dan kesejahteraan bersama

j. Menjunjung tinggi nilai kekeluargaan

k. Tidak menggunakan hak milik untuk melakukan usaha-usaha yang bersifat pemerasan terhadap orang lain

Visi Pancasila dalam perubahan sosial merupakan proses interaksi timbal balik antara tindakan manusia dan nilai moral Pancasila. Relasi ini bersifat dinamis. Perubahan sosial dipengaruhi kualitas manusia, demikian pula sebaliknya. Wujud nilai dan moral Pancasila pada aspek sosial, budaya, politik dan ekonomi ini dapat diklasifikasikan menjadi dua, yaitu nilai dan moral Pancasila yang mendasari tataran 
individual dan kolektif. Secara individual, nilai ini terlihat pada pengakuan akan kebebasan dan persamaan sebagai hak individual. Secara kolektif, nilai dan moral Pancasila berupa hak atas pekerjaan, keadilan, beragama, dan kesejahteraan yang akan menjamin kebebasan dan persamaan hak individu (Prayitno 2014; Syamsir et al. 2017).

Untuk membentengi pengaruh yang kurang baik dari sosial dan budaya asing, maka Pancasila harus diutamakan. Yang diharapkan adalah kehidupan yang rukun dan harmonis, saling menghargai satu sama lain. Namun kehidupan sosial budaya sekarang cenderung lebih ke arah individualis dan kepentingan kelompok maupun golongan tertentu. Sebagai negara yang terdiri dari berbagai suku, budaya, agama, adat istiadat, dan bahasa, maka perbedaan tersebut sering dijadikan alasan untuk memprovokasi perpecahan antara golongan satu dengan golongan yang lain. Rasa nasionalisme terhadap bangsa kini sebagian mulai memudar. Hal ini bisa dicegah jika kita mengamalkan Bhineka Tunggal lka dan Pancasila secara bersungguh-sungguh dan sepenuh hati (Inahasari and Dewantara 2019).

Pancasila adalah dasar negara yang mengatur bahwa semua orang memiliki hak dan kedudukan yang sama. Tidak ada perbedaan sosial budaya, suku, agama, ras, ataupun golongan. Sebagai ideologi negara, Pancasila memberi landasan filosofis bersama. Masyarakat Indonesia yang maju, berdaulat, adil dan makmur adalah tujuan utamanya. Tantangan utama adalah selalu berusaha memiliki karakter yang kuat sehingga selalu berusaha maju tanpa terus meributkan perbedaan yang ada (Prayitno 2014).

Pancasila adalah dasar bagi perubahan sosial budaya ke arah yang lebih baik. Melalui perspektif interaksi sosial, akan mampu menganalisis secara cermat segala fenomena sosial yang terjadi. Hal ini akan mendukung kehidupan masyarakat Indonesia ke arah yang mantap dan dinamis (Prayitno 2014).

Pemahaman dan penerapan nilai-nilai Pancasila dapat mendorong warga negara Indonesia untuk lebih mengutamakan persatuan dalam perbedaan. Kepentingan negara akan lebih diutamakan daripada kepentingan individu dan kelompok. Kehidupan sosial budaya yang didasarkan pada nilai-nilai Pancasila dapat dimulai dari diri sendiri. Contohnya dengan menghormati adanya perbedaan agama, meningkatkan sikap tenggang rasa terhadap semua manusia dari segala golongan dan latar belakang sosial budaya apapun, menjunjung tinggi martabat dan hak-hak asasi manusia, mengedepankan sosial kemasyarakatan, serta sikap hidup kekeluargaan dan gotong royong (Inahasari and Dewantara 2019).

Melalui penerapan sila-sila dalam Pancasila, semua warga negara akan mengenal dan berhubungan baik dengan saudara sebangsa dan setanah air, tidak mudah terprovokasi, siap bela negara, dan ikut serta menjadi Sumber Daya Manusia yang unggul untuk diri sendiri serta demi negara tercinta ini. Sosial dan budaya ini erat kaitannya dengan kualitas Sumber Daya Manusia. Pada akhirnya akan tercipta Sumber Daya Manusia yang unggul, mandiri, dan berbudaya. Tujuan negara yaitu kesejahteraan dan kedamaian semua warga negara akan terwujud (Inahasari and Dewantara 2019).

\section{Kondisi sosial budaya Indonesia saat ini}

Kondisi sosial budaya masa kini sebagian sudah menyimpang dari nilai-nilai moral. Penyimpangan ini dapat dilihat pada generasi milenial yang cara berpakaian, berbicara, dan bertingkah laku lebih menyerupai budaya barat. Jika yang dicontoh adalah kebiasaan baik, maka hal ini akan memberikan kemajuan yang pesat sekali. Kebiasaan baik tersebut adalah disiplin waktu, bekerja keras, etos kerja yang tinggi, teknologi yang canggih, tertib dalam menjaga kebersihan di tempat umum, maupun selalu meningkatkan dan memperbaiki diri. Namun yang ditiru juga ada yang buruk seperti minum-minuman keras, seks bebas, video porno, terror geng, permusuhan antar remaja, tawuran di sekolah, narkoba, gaya berpakaian yang kurang etis, maupun 
kurang menghargai generasi pendahulu. Hal-hal tersebut sangat menyimpang dari norma-norma agama dan kesusilaan (Roziq 2016). Seharusnya semua ini mesti dipilih dan dipilah terlebih dahulu sebelum diadopsi secara mentah-mentah dan dipakai langsung (Inahasari and Dewantara 2019).

Cara membentengi diri dari pengaruh sosial budaya yang kurang baik adalah memperkuat iman dan pengetahuan. Pengetahuan agama akan membantu meningkatkan kontrol diri para remaja. Orangtua harus berperan aktif dalam mengingatkan dan membimbing putra-putrinya setiap saat. Orangtua harus menjadi tempat pertama bagi anak-anaknya untuk mencurahkan isi hati dan segala permasalahan yang dihadapi. Jangan sampai anak-anak mencari perlindungan dan tempat menuangkan isi hati di luar rumah. Hal ini akan berdampak pada pergaulan yang salah. Sering kita dengar ada yang berkenalan melalui sosial media, lalu terjadi hal buruk seperti penculikan, pelecehan, maupun perampokan (Inahasari and Dewantara 2019).

Nilai-nilai dalam Pancasila ini memandang relasi individu dan struktur sosial budaya dalam masyarakat secara timbal balik. Keadaan ini akan berdampak pada kualitas perubahan sosial di tengah masyarakat. Pancasila akan terwujud dalam nilai dan moralitas pada tataran individual sekaligus masyarakat (Prayitno 2014).

Norma-norma sosial budaya lingkungan keluarga dan pendidikan agama menjadi bagian krusial untuk terwujudnya sosial budaya yang positif. Melalui teknologi, dapat diwujudkan berbagai kegiatan sosial kemanusiaan yang positif. Hal ini akan berdampak pada peningkatan kesadaran masyarakat untuk berbagi. Contohnya adalah melalui media sosial memberikan informasi mengenai kegiatan untuk berbagi kasih dengan sesama (Inahasari and Dewantara 2019).

Sikap saling menghargai ini akan mempererat tali persaudaraan. Kegiatan sukarelawan juga bisa dilakukan oleh para pemuda ataupun organisasi kemasyarakatan setempat. Hal ini bisa diwujudkan sekalipun di pelosok tanah air. Pengabdian masyarakat bisa dilakukan oleh para generasi muda. Kegiatan seperti ini akan menghasilkan generasi yang berkualitas, cinta tanah air, dan berbudaya (Inahasari and Dewantara 2019).

\section{Sosial Budaya dalam kehidupan berpolitik}

Kehidupan sosial budaya yang baik dalam atmosfer berpolitik adalah mempertahankan karakter yang baik dalam melaksanakan tugas pemerintahan. Tugas ini bisa dimulai dari lingkungan yang paling kecil di Rukun Tetangga (RT), Rukun Warga (RW), kecamatan, kabupaten, bahkan sampai pemerintah pusat. Karakter yang baik adalah jujur, bijaksana, dan adil. Jangan sampai terjadi korupsi karena budaya politik uang yang makin menjamur. Moral, etika, dan karakter sosial dan budaya di Indonesia harus dilandaskan pada nilai-nilai Pancasila (Inahasari and Dewantara 2019).

\section{Interaksi Sosial Budaya yang berlandaskan Pancasila}

Untuk mewujudkan hubungan yang harmonis antar berbagai suku bangsa dalam interaksi sosial, diperlukan adanya faktor sosial untuk mengeliminasi perbedaan yang ada. Bentuk eliminasi tersebut adalah pola hubungan yang bersifat "simbiosis mutualisme" antar-etnis yang berbeda, dalam berbagai kegiatan. Komunikasi dan hubungan sosial yang intensif akan meningkatkan pemahaman satu sama lain. Pemahaman akan meningkatkan rasa saling mengerti. Kesadaran bahwa perbedaan itu hal yang lumrah dan tidak perlu merasa lebih superior dari yang lainnya. Semuanya setara satu sama lainnya (Prayitno 2014).

Sebenarnya ada dua ciri etnik yang sangat bertolak belakang, yaitu hot ethnicity dan cold ethnicity. Hot etnicity cenderung menonjolkan identitas etniknya. Mereka selalu ingin merdeka. Kelompok kedua, yaitu cold ethnicity adalah kelompok yang sifatnya kurang fanatik. Mereka kurang emosional. Indonesia memiliki kedua ciri ini. Untuk mengelola kedua kelompok ini, diperlukan satu identitas nasional bersama, 
yaitu Pancasila. Pancasila memberikan kebebasan, mengembangkan sistem sosial budaya, dan saling menghargai (Prayitno 2014).

\section{Pancasila sebagai Visi Bangsa}

Sebagai visi negara, Pancasila dapat dijadikan dasar perubahan sosial. Tujuannya adalah terbentuknya masyarakat multikultural yang rukun, berdaulat, adil, dan makmur. Harus dikembangkan sikap toleransi dengan nilai keselarasan. Memaknai hidup dalam upaya saling menghormati dan menjunjung tinggi nilai kemanusiaan akan meningkatkan terciptanya kedamaian dalam kondisi sosial budaya yang berbeda namun selaras (Prayitno 2014).

Ada empat usaha yang perlu dilakukan oleh masyarakat dalam mewujudkan Pancasila sebagai landasan dalam kehidupan sosial budaya. Usaha tersebut yaitu melestarikan nilai yang ada, beradaptasi dengan perubahan dunia, saling bersatu, serta memiliki cita-cita, pandangan, harapan, dan tujuan yang sama tentang masa depannya. Jika semua individu melaksanakan hal ini, maka visi Pancasila akan selalu terjaga (Prayitno 2014).

Visi pembangunan nasional dari 2005-2025 adalah Indonesia yang mandiri, maju, adil dan makmur. Pancasila dapat dijadikan pedoman dalam proses mencapai visi pembangunan ini. Melalui pendidikan, terjadilah proses sistematis untuk meningkatkan martabat manusia secara holistik. Kemampuan untuk meningkatkan afektif, kognitif, dan psikomotorik dilakukan secara optimal demi mengembangkan karakter dan wawasan kebangsaan. Pendidikan karakter adalah usaha sadar untuk mendidik sehingga mereka dapat memberikan kontribusi positif terhadap lingkungan (Roziq 2016).

\section{Upaya melestarikan nilai Pancasila dalam kehidupan sosial budaya}

Upaya melestarikan nilai Pancasila dalam kehidupan sosial budaya bersendi pada etika dan moral. Melalui pendidikan akan mampu menciptakan generasi muda yang beretika luhur. Manusia yang bersemangat dan cerdas akan mampu menjaga dan melestarikan nilai-nilai Pancasila dengan baik. Karakter yang baik adalah kekuatan negara ini. Kesejahteraan dan kedamaian negara akan terwujud jika semua orang memiliki karakter yang baik berdasarkan nilai-nilai Pancasila (Prayitno 2014).

Pendidikan karakter mengutamakan tiga hal pokok. Ketiga hal tersebut adalah mengetahui, perasaan moral yang moral, dan perilaku moral. Tujuan pendidikan karakter adalah membangun bangsa yang kuat, kompetitif, bermoral serta berbudi, akhlak mulia baik, toleransi, bekerja sama, semangat patriotik, dan berkembang dinamis. Proses yang dilakukan hendaknya menggunakan ilmu pengetahuan dan teknologi yang berorientasi dengan iman dan takwa kepada Tuhan Yang Maha Esa berdasarkan Pancasila. Melalui akulturasi dan pendidikan pemberdayaan karakter bangsa, maka siswa dapat menumbuhkan nilai-nilai Pancasila dalam praktek hidup sehari-hari (Roziq 2016).

Sosial budaya di Indonesia sangat beraneka ragam. Setiap daerah memiliki karakteristik budaya yang berbeda. Hendaknya diambil segi positifnya semua. Misalnya budaya tepat waktu, kreatif, inovatif, disiplin, dan segera menyelesaikan pekerjaan yang ada. Kebiasaan yang dilakukan berulang-ulang tentunya akan menjadi karakter yang baik. Dari hal kecil inilah jika dilakukan secara rutin oleh semua warga negara Indonesia, maka hal ini akan berdampak bagi kesejahteraan bangsa Indonesia (Inahasari and Dewantara 2019).

Beberapa prinsip untuk menjadikan Pancasila sebagai dasar perubahan sosial budaya ke arah yang lebih baik adalah menciptakan interaksi yang sehat dalam masyarakat, meningkatkan keunggulan masing-masing individu, serta menanggapi segala persoalan yang muncul secara proaktif. Reaktif maupun represif harus dihindari supaya tidak terjadi kekerasan (Prayitno 2014).

Pendekatan sosiologi yang digunakan bersifat saling bergantung. Kerjasama satu sama lain diperlukan untuk mencapai tujuan bersama. Nilai-nilai yang dibagi 
bersama itu bersifat universal, sehingga tidak memperbesar jurang perbedaan yang ada (Prayitno 2014).

\section{Menempatkan Pancasila sebagai Arah Perubahan Sosial}

Pancasila adalah identitas bangsa Indonesia. Pancasila juga merupakan konsep dan nilai-nilai yang mengatur hubungan antara manusia dan Tuhan, antarsesama manusia, serta antara manusia dan alam semesta. Hal ini tampak dalam silasila Pancasila yaitu nilai ketuhanan, kemanusiaan, persatuan, kerakyatan, dan keadilan sosial. Hubungan ini bersifat dinamis dan berperan untuk pembentukan karakter bangsa. Kerjasama segenap komponen bangsa diperlukan untuk mewujudkan bangsa yang berkarakter. Pancasila sebagai arah perubahan sosial terwujud melalui peningkatan kemampuan masyarakat dalam mengapresiasi pesan moral yang terkandung pada setiap sila Pancasila (Prayitno 2014).

\section{Nilai-nilai Pancasila sebagai Sumber dari Karakter Bangsa, Budaya dan Pendidikan}

Pendidikan sejak dini dimulai di lingkungan keluarga. Sekolah adalah tempat pendidikan formal. Pancasila sebagi sumber pendidikan karakter artinya Pancasila ini adalah dasar filosofis bangsa Indonesia. Jika pendidikan di sekolah maupun di rumah selalu menekankan nilai-nilai Pancasila, niscaya kehidupan sosial budaya akan tertib dan damai. Secara garis besar, nilai-nilai yang diterapkan adalah nilai-nilai Ketuhanan Yang Maha Esa, Kemanusiaan, Persatuan, Demokrasi, dan Keadilan. Pada dasarnya, Pancasila mengandung nilai-nilai budaya bangsa (Roziq 2016).

Mengintegrasikan nilai-nilai Pancasila dalam pendidikan karakter berbasis budaya menggunakan pendekatan fenomenologis. Pelajar perlu memahami dan mengamalkan nilai-nilai, norma, dan moral berdasarkan Pancasila, dan nilai-nilai sosial budaya bangsa. Dampak globalisasi dan kemajuan ilmu pengetahuan seyogyanya dibarengi dengan mengintegrasikan nilai-nilai Pancasila dalam pendidikan karakter berbasis budaya (Roziq 2016).

Integrasi nilai-nilai Pancasila dalam pendidikan karakter berbasis budaya menggunakan prinsip-prinsip sebagai berikut (Roziq 2016):

a. Nilai-nilai Pancasila adala sumber nilai berbasis karakter nasional untuk pendidikan yang dikembangkan sesuai dengan budaya nasional dengan tetap memperhatikan pengetahuan lokal sehingga mudah dipahami, dihayati, dan dilaksanakan.

b. Pendidikan karakter menitikberatkan pada domain kognitif, afektif, psikomotor, dan sosial.

c. Keluarga adalah media yang paling efektif dalam pendidikan karakter

d. Program ekstra kurikuler harus terintegrasi dengan nilai Pancasila

e. Menanamkan konsep dasar Pancasila, UUD 1945 dalam Negara Kesatuan Republik Indonesia (NKRI), dan ber-Bhinneka Tunggal untuk semua jenjang pendidikan, dari yang paling dasar sampai paling tinggi, serta segala sektor pendidikan baik dalam bentuk formal maupun informal

f. Menguatkan Pendidikan Pancasila dan Pendidikan Kewarganegaraan, serta identitas nasional untuk mencapai cita-cita bangsa Indonesia yang adil dan makmur.

g. Melaksanakan pendidikan karakter nasional yang tersirat dalam pendidikan kewarganegaraan adalah tanggung jawab bersama. Tugas ini bukan hanya sebagai bagian dari mata pelajaran atau mata kuliah PKn tetapi harus menjadi tanggung jawab bersama dari semua subyek pendidikan nasional.

h. Pendekatan yang dikembangkan adalah pendekatan multidispliner dan multidimensi yang holistik. Hasil akhir yang diharapkan adalah menjadi bangsa yang mempunyai sikap mental yang kuat 


\section{SIMPULAN}

Nilai-nilai Pancasila sangat penting diterapkan dalam kehidupan sosial budaya, terlebih di era moden ini. Peran Pancasila dalam pengembangan sosial budaya berdasarkan karakter sangatlah besar. Hal ini bisa dimulai dari pengamalan masingmasing sila dalam Pancasila, terutama sila kedua, ketiga, dan kelima. Harapannya adalah tercipta manusia yang cerdas, mandiri, berbudaya, dan berkarakter luhur.

\section{DAFTAR PUSTAKA}

Amalia, Taranindya Zulhi. 2013. "Multicultural Education , The Frame Of Learning Islamic Studies Towards Islamic Religion Teachers Bilingually." Qudus International Journal Of Islamic Studies 1 (1): 77-90.

Hoon, Chang-yau. 2020. "Putting Religion into Multiculturalism : Conceptualising Religious Multiculturalism in Indonesia Putting Religion into Multiculturalism : Conceptualising Religious Multiculturalism in Indonesia." Asian Studies Review 41 (3): 476-93. https://doi.org/10.1080/10357823.2017.1334761.

Inahasari, Endah Dwi, and Agustinus W Dewantara. 2019. "Peran Pancasila Dalam Kehidupan Sosial Dan Budaya." Fakultas Ekonomi Dan Bisnis Program Studi Manajemen Universitas Katholik Widya Mandala Surabaya Kampus Madiun, 114.

Prayitno, Ujianto Singgih. 2014. "Pancasila Dan Perubahan Sosial: Perspektif Individu Dan Struktur Dalam Dinamika Interaksi Sosial." Aspirasi 5 (2): 107-18.

Roziq, M. Abdul. 2016. "Integrasi Nilai-Nilai Pancasila Dalam Pendidikan Karakter Dan Budaya Bangsa Yang Berbasis Pada Lingkungan Sekolah.” Jurnal Rontal Keilmuan PPKn 2 (1): 1-11.

Syamsir, Ali Amran, Mashudi, and Surya Dharma. 2017. "Pendidikan Pancasila Untuk Perguruan Tinggi." Buku Ajar Bersama BKS PTN-Barat, 1-269. 